\title{
Phytochemical Comparison of the Water and Ethanol Leaf Extracts of the Cree medicinal plant, Sarracenia purpurea L. (Sarraceniaceae)
}

\author{
Carolina Cieniak $^{1}$, Brendan Walshe-Roussel ${ }^{1}$, Rui Liu ${ }^{1}$, Asim Muhammad ${ }^{2}$, Ammar Saleem ${ }^{1}$, Pierre S. Haddad ${ }^{3}$, Alain \\ Cuerrier $^{4}$, Brian C. Foster ${ }^{5}$, John T. Arnason ${ }^{1}$. \\ ${ }^{1}$ Biology Department, University of Ottawa, Ottawa, ON, Canada. ${ }^{2}$ Department of Chemistry, University of Ottawa, \\ Ottawa, ON, Canada. ${ }^{3}$ Department of Pharmacology, Université de Montréal, Montréal, QC, Canada. ${ }^{4}$ Jardin botanique de \\ Montréal, Institut de recherche en biologie végétale, Université de Montréal, Montréal, QC, Canada. ${ }^{5}$ Department of \\ Cellular and Molecular Medicine, University of Ottawa, Ottawa, ON, Canada.
}

Received, June 30, 2015; Revised, August 9, 2015; Accepted, August 28, 2015; Published, September 1, 2015.

\begin{abstract}
Purpose: The Cree of Eeyou Istchee in Northern Quebec identified Sarracenia purpurea L. as an important plant for the treatment of Type 2 diabetes. Traditionally the plant is used as a decoction (boiling water extract) of the leaf, however, in order to study the extract in a laboratory setting, an $80 \%$ ethanol extract was used. In this study, the phytochemistry of both extracts of the leaves was compared and quantified. Methods: Two S. purpurea leaf extracts were prepared, one a traditional hot water extract and the other an $80 \%$ ethanol extract. Using UPLC-ESI-MS, the extracts were phytochemically compared for 2 triterpenes, betulinic acid and ursolic acid, using one gradient method and for 10 additional substances, including the actives quercetin-3-O-galactoside and morroniside, using a different method. Results: The concentrations of the nine phenolic substances present, as well as an active principle, the iridoid glycoside morroniside, were very similar between the two extracts, with generally slightly higher concentrations of phenolics in the ethanol extract as expected. However, two triterpenes, betulinic acid and ursolic acid, were 107 and 93 times more concentrated, respectively, in the ethanol extract compared to the water extract. Conclusion: The main phytochemical markers and most importantly the antidiabetic active principles, quercetin-3-O-galactoside and morroniside, were present in similar amounts in the two extracts, which predicts similar bioactivity.
\end{abstract}

This article is open to POST-PUBLICATION REVIEW. Registered readers (see "For Readers") may comment by clicking on ABSTRACT on the issue's contents page.

\section{INTRODUCTION}

Traditional medicine continues to be an important part of the culture for the Cree First Nation of Eeyou Istchee in Northern Quebec. They use plants to treat the symptoms and causes of many diseases, and traditionally prepare most of their plant extracts as decoctions (boiling water extracts). In 2003, a number of Cree First Nations of Eeyou Istchee as well as the Cree Health Board initiated a research project in collaboration with six university laboratories, named the CIHR Team in Aboriginal Antidiabetic Medicines (CIHR-TAAM) (http://www.taam-emaad.umontreal.ca/), to evaluate the safety and efficacy of culturally relevant medicines used to treat symptoms of Type 2 diabetes $(1,2)$. This disease is particularly important as the prevalence of diabetes is greater than $20 \%$ in the Cree adult population (3) and compliance with conventional therapies is low.
It is well known that different solvents are able to extract different families of phytochemicals based on their polarity, hence varying the biological activity of the extracts (4-6). Alcohol extracts are preferred to water extracts in many pharmacological assays, as many lipophilic bioactive secondary metabolites, notably phenolics are more efficiently extracted than with water. In addition to the phytochemicals found in ethanolic extracts, hot water also tends to extract other biological components (7), such as hydrophilic polysaccharides and denatured proteins, which may interfere with some assays (8). However, the phytochemistry of the two types of plant extracts is

Correspondence Author: Brian C. Foster, Ph.D., Faculty of Medicine, Department of Cellular and Molecular Medicine, University of Ottawa, Ottawa, ON, K1H 8M5, Canada. Email: bfoste2@uottawa.ca. 
very seldom compared in medicinal plant research, even when traditionally prepared boiled water extracts are used for therapy.

One of the main plant species identified by the Cree for its antidiabetic properties was Sarracenia purpurea L. (Sarraceniaceae), the pitcher plant, also known as Ayigadash in Cree (1). It is a carnivorous plant found to inhabit bogs and other nitrogen-poor environments (9). A quantitative ethnobotanical survey by Leduc et al. (1) showed that $S$. purpurea was an important plant species used to treat the symptoms of diabetes by the Cree, and it was identified as one of the priority plant species for the TAAM to study. Therefore, a robust phytochemical comparison of the traditional water and the ethanol extracts was necessary to examine the targeted substances previously identified in S. purpurea (10) (Figure 1).
1<smiles>Oc1cc(O)c2c(c1)OC(c1ccc(O)c(O)c1)[C@H](O)C2</smiles>

4<smiles>O=C1c2c(O)cc(O)cc2OC(c2ccc(O)c(O)c2)C1O[C@H]1OC(CO)[C@@H](O)[C@H](O)[C@H]1O</smiles><smiles>O=c1c(O[C@@H]2O[C@H](CO)[C@@H](O)[C@H](O)[C@H]2O)c(-c2ccc(O)c(O)c2)oc2cc(O)cc(O)c12</smiles>

2<smiles>COC(=O)C1=CO[C@@H](O[C@@H]2OC(CO)[C@@H](O)[C@H](O)[C@H]2O)[C@@]2(C)C(C)O[C@H](O)CC12C</smiles>

5

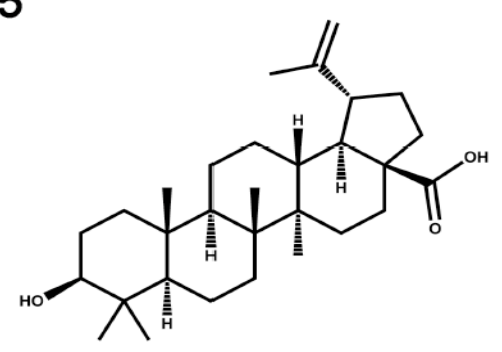

8

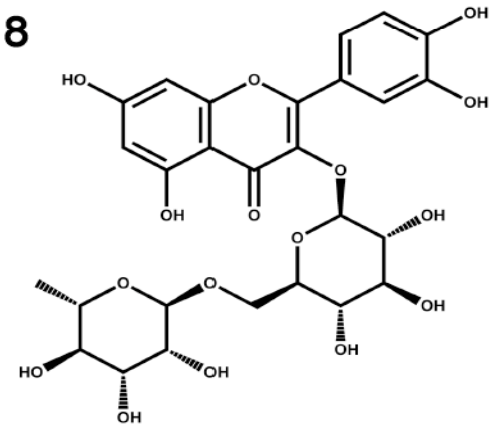

3<smiles>Oc1cc(O)c2c(c1)OC(c1ccc(O)c(O)c1)C[C@H]2O</smiles>

6

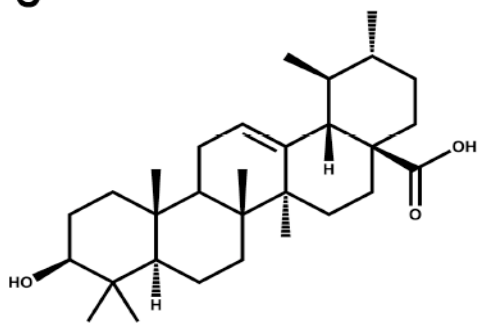

9<smiles>O=c1c(O[C@@H]2O[C@H](CO)[C@@H](O)[C@H](O)[C@H]2O)c(-c2ccc(O)c(O)c2)oc2cc(O)cc(O)c12</smiles>

12<smiles>CC1OC(OCC2OC(Oc3c(-c4ccc(O)cc4)oc4cc(O)cc(O)c4c3=O)C(O)C(O)C2O)C(O)C(O)C1O</smiles>

Figure 1. Chemical structure of compounds in Sarracenia purpurea. 1. (+)-catechin, 2. morroniside, 3. (-)-epicatechin, 4. taxifolin-3-O-glucoside, 5. betulinic acid, 6. ursolic acid, 7. quercetin-3-O-galactoside, 8. rutin, 9. quercetin-3-O-glucoside, 10. luteolin-7-O-glucoside, 11. myricetin, 12. kaempferol-3-O-rutinoside. 
The purpose of this work was to quantify the differences, particularly for those substances known to have antidiabetic activity.

\section{MATERIALS AND METHODS}

\section{Chemicals and Standards}

The standards (purity >95\%) (+)-catechin, (-)epicatechin, luteolin-7-O-glucoside, kaempferol-3O-rutinoside, betulinic acid, ursolic acid, and rutin were all purchased from Extrasynthese (Genay Cedex, France). Quercetin-3-O-galactoside, quercetin-3-O-glucoside, and myricetin were purchased from Sigma Aldrich (Oakville, ON, Canada). Morroniside was purchased from AvaChem Scientific (San Antonio, TX, USA) and taxifolin-3-O-glucoside was isolated in-house and its structure and purity was verified through its ultraviolet (UV) spectrum, mass spectrometry (MS) and nuclear magnetic resonance (NMR) (11). All solvents were LC-MS grade and purchased from Fisher Scientific (Ottawa, ON, Canada).

\section{Plant extracts}

S. purpurea L. leaves were collected in August 2008 in a bog in the Eastern James Bay Region in Quebec, Canada according to healer's and Elder's instructions and under permit from the TAAM Cree Nation Intellectual Property agreement. Its identity was confirmed by Dr. A. Cuerrier from the Montreal Botanical Garden and a voucher specimen \#2003-05 was deposited at the Marie-Victorin herbarium at the Montreal Botanical Garden $(1,2)$. The pitchers of the plant were cut open and cleaned of any potential insects or debris and dried in an electric food dehydrator (Nesco/American Harvest, Two Rivers, WI, USA) at $40^{\circ} \mathrm{C}$. The leaves were then ground to a powder using a Thomas Wiley Mill (1 mm filter) (Thomas Scientific, Swedesboro, NJ, USA). Subsequently, two different types of extracts were prepared.

The ethanol extract was prepared using $80 \%$ ethanol in a ratio of $10 \mathrm{~mL}$ per gram of dry ground plant material extracted at room temperature overnight under gentle agitation. The extract was then separated from the plant residue by vacuum filtration using a Whatman qualitative no.1 filter (11 $\mu \mathrm{m}$ pore size) (Whatman plc, Maidstone, Kent, UK). The residue was then extracted two more times using the same method described above. The filtered extracts were then combined and the ethanol evaporated using a rotary evaporator at $40^{\circ} \mathrm{C}$ and residual water removed through lyophilisation. The water extract was prepared by gently boiling the plant material in distilled water for one hour in a ratio of $10 \mathrm{~mL}$ per gram of dry plant material to approximate the preparation method used by the Healers. The extract was then separated from the plant residue as above and dried using a B-191 Büchi Mini Spray Dryer (Büchi, Switzerland) operating with an inlet temperature of $150^{\circ} \mathrm{C}$ and an air flow rate of $600 \mathrm{~L} /$ hour. Both the ethanol and water extracts were ground with a mortar and pestle into homogenous powders and resuspended in methanol and filtered prior to analysis.

\section{Ultra performance liquid chromatography - electrospray ionization - mass spectrometry (UPLC-ESI-MS)}

The analytical methodology was based on Saleem et al. (12) with slight modifications. Briefly, the identification and quantification of the 12 target substances was performed using a Shimadzu UPLC-MS system (Mandel Scientific Company Inc, Guelph, ON, Canada). The system consisted of a binary pump (LC30AD), a column thermostat (CTO20a), a high performance autosampler (SIL30AC), a photodiode array detector (SPD-M20A) and a mass selective detector LC2020. Electrospray source was operated in positive and negative ionization modes (Table 1). The nebulizing gas flow was set at $1.5 \mathrm{~L} / \mathrm{min}$ and drying gas flow was at $10 \mathrm{~L} / \mathrm{min}$. The desolvation line temperature and heat block temperature were set at $300^{\circ} \mathrm{C}$ and $450^{\circ} \mathrm{C}$ respectively. Identification of separated substances was undertaken by co-chromatographic comparison of the retention time and mass data with commercially available purified standards. A Shimadzu Lab Solutions software (5.41.240) was used for the quantification of identified substances. Standard curves (5 to $100 \mathrm{ng}$ ) were built by injecting dilutions of the standard substances in order to obtain peak areas to automatically quantify the amount of each marker substance. Each sample was analyzed in triplicate and peak response averaged to account for instrumental variation; the $\mathrm{r}^{2}$ values were all greater than 0.99 (data not shown).

Two separation gradients were employed. Method A for the triterpenes including betulinic acid and ursolic acid, and method B for the phenolics. Separations were performed on a Phenomenex Kinetex C18 column $(2.6 \mu \mathrm{m}$ particle size, $100 \mathrm{~mm} \times 2.1 \mathrm{~mm}$, Phenomenex Inc., 
Torrence, CA, USA) with corresponding guard column to achieve enhanced separation. The injection volumes were $1 \mu \mathrm{L}$, flow was set to 0.4 $\mathrm{mL} / \mathrm{min}$ with a column temperature of $55^{\circ} \mathrm{C}$. Method A, isocratic elution method with $62.5 \%$ acetonitrile $(\mathrm{ACN})$ with $37.5 \%$ water for $5 \mathrm{~min}$. Method $\mathrm{B}$, gradient elution method with $0.1 \%$ formic acid (solvent A) and 70\% ACN with $30 \%$ $\mathrm{MeOH}$ and $0.1 \%$ formic acid (solvent $\mathrm{B}$ ). The gradient was initially set at $86 \%$ A for $5.5 \mathrm{~min}$, followed by $65 \% \mathrm{~A}$ isocratic for $2 \mathrm{~min}$. The column was then washed for 2 min with $100 \%$ of solvent B and then returned to initial condition.

\section{Lipophilicity}

The partition coefficient $\log \mathrm{P}$, a measure of lipophilicity, was evaluated using ChemBioDraw Ultra 13.0 software (Perkin Elmer, Waltham, MA, USA).

\section{STATISTICAL ANALYSIS}

Data were analysed using GraphPad Prism 6.0 software (GraphPad Software Inc., La Jolla, CA, USA) using a multiple t-test comparing the concentration of each marker substance between the extracts. A false discovery rate was set to $1 \%$.

\section{RESULTS}

The water extraction produced a powder at a yield of $20.6 \% \mathrm{w} / \mathrm{w}$ dried plant material, while the ethanol extraction produced a resinous/glassy extract at a yield of $36.9 \% \mathrm{w} / \mathrm{w}$. Two different UPLC-ESI-MS methods used to analyze the ethanol and water extracts of the leaves of S. purpurea provided good chromatographic resolution (Figure 2 ) of the 12 targeted substances. In the ethanol extract, the peaks representing betulinic acid (5), ursolic acid (6), morroniside (2), (-)-epicatechin (3), taxifolin-3-O-glucoside (4) and quercetin-3-Ogalactoside (7) were present in high enough quantities to be visible on the chromatogram. Their identification in the extracts was achieved based on selective ion monitoring for particular mass over charge $(\mathrm{m} / \mathrm{z})$ and retention times (Table 1) compared to pure standards. In the water extract, the same substances were identifiable, however at a lower concentration.

As shown in Figure 2, the relative abundance of the phytochemicals varied between the water and ethanol extracts. This was quantified in Table 2, where the amount of (+)-catechin (1) and morroniside (2) was significantly greater in the water extract compared to the ethanol extract $(p<0.001)$. The concentration ratio $\left(E t O H: \mathrm{H}_{2} \mathrm{O}\right)$ for these two marker substances was 0.43 and 0.83 , respectively. Thus 2 was slightly less concentrated in ethanol. Conversely, the phenolic substances (-)epicatechin (3), taxifolin-3-O-glucoside (4), quercetin-3-O-galactoside (7), and quercetin-3-Oglucoside (9) were present in significantly higher quantities ( $<<0.001$ and $p<0.01$ for 9 ) in the ethanol extract compared to the water extract with EtOH: $\mathrm{H}_{2} \mathrm{O}$ concentration ratios of 1.64, 2.32, 1.67, and 1.25 , respectively.

Table 1. List of identification parameters for the twelve targeted substances used in the quantification of marker compounds in the leaves of Sarracenia purpurea using UPLC-ESI-MS. Compounds are numbered in order of retention time.

\begin{tabular}{llllll}
\hline Peak & Compound & Separation method & Ionization mode & Retention time $(\mathrm{min})$ & Ion detected $(\mathrm{m} / \mathrm{z})$ \\
\hline 1 & (+)-catechin & B & Positive & 1.65 & $291\left(\mathrm{M}+\mathrm{H}^{+}\right)$ \\
2 & Morroniside & B & Positive & 1.83 & $429\left(\mathrm{M}+\mathrm{Na}^{+}\right)$ \\
3 & (-)-epicatechin & B & Positive & 2.12 & $291\left(\mathrm{M}+\mathrm{H}^{+}\right)$ \\
4 & Taxifolin-3-O-glucoside & B & Negative & 2.49 & $465\left(\mathrm{M}-\mathrm{H}^{+}\right)$ \\
5 & Betulinic acid & A & Negative & 3.38 & $455\left(\mathrm{M}-\mathrm{H}^{+}\right)$ \\
6 & Ursolic acid & A & Negative & 3.62 & $455\left(\mathrm{M}-\mathrm{H}^{+}\right)$ \\
7 & Quercetin-3-O-galactoside & B & Positive & 4.88 & $487\left(\mathrm{M}+\mathrm{H}^{+}\right)$ \\
8 & Rutin & B & Negative & 5.12 & $609\left(\mathrm{M}-\mathrm{H}^{+}\right)$ \\
9 & Quercetin-3-O-glucoside & B & Positive & 5.35 & $487\left(\mathrm{M}+\mathrm{H}^{+}\right)$ \\
10 & Luteolin-7-O-glucoside & B & Positive & 5.67 & $449\left(\mathrm{M}+\mathrm{H}^{+}\right)$ \\
11 & Myricetin & B & Positive & 7.32 & $319\left(\mathrm{M}+\mathrm{H}^{+}\right)$ \\
12 & Kaempferol-3-O-rutinoside & B & Negative & 7.64 & $593\left(\mathrm{M}-\mathrm{H}^{+}\right)$ \\
\hline
\end{tabular}


The triterpenes, betulinic acid (5) and ursolic acid (6), were also more abundant in the ethanol extract $(\mathrm{p}<0.001)$, and here the magnitude of the difference was much greater as they were about 107 and 93 times more abundant in the ethanol extract, respectively. Kaempferol-3-O-rutinoside (12) and rutin (8), minor substances in $S$. purpurea, were detected in trace amounts and below the limit of accurate quantitation. On the other hand, luteolin-7O-glucoside (10) and myricetin (11) were not detected in the samples analyzed.

Evaluation of lipophilicity as determined by $\log \mathrm{P}$ values showed that the majority of the substances had values between -2.28 and 1.5 (Table $3)$. This included all the phenolics and the iridoid glycoside, morroniside (2). The two triterpenes, betulinic acid (5) and ursolic acid (6) had significantly higher $\log \mathrm{P}$ values of 7.38 and 7.33 , respectively.

\section{DISCUSSION}

This study is the first comparing the phytochemical content of $S$. purpurea extracts prepared in two different ways. The water extraction used in this study was consistent with the traditional preparation used by the Cree of Eeyou Istchee whereas the ethanol extract is preferentially used in most pharmacological studies examining the activity of medicinal plants. This comparison was important for the Cree Healers as they wanted to know that the phytochemicals present and active in these assays were also the same ones present in their traditional preparation. It was shown here that the $80 \%$ ethanol extract generally results in significantly higher quantities of phenolics present, as well as the triterpenes. The only exceptions were the two most polar substances present $(+)$-catechin (1) and morroniside (2).

This result was not surprising as higher quantities of phenolics have been consistently seen by other groups in alcohol extracts $(7,13,14)$. In fact, this is one of the reasons why alcohol extracts are preferred in bioassays since relevant biological activities, such as antioxidant activity, are easier to observe in extracts with a greater phenolic concentration. Alcohols, being less polar solvents, are able to break down plant cell walls more efficiently and hence extract the necessary components (13). However, pure alcohol extracts are less efficient than alcohol/water mixtures (15). The $80 \%$ ethanol/water mixture normally used for extraction was optimized previously in the laboratory for phenolic extraction $(16,17)$. Also, it is understandable that (+)-catechin (1) and morroniside (2) were present in significantly higher quantities in the water extract. They are the two most polar marker substances examined, as can be

Table 2. Quantification of phytochemicals in ethanol and water extracts of Sarracenia purpurea using UPLC-ESI-MS. The concentration of each compound in each extract is presented in $\mathrm{mg} / \mathrm{g}$. Means of three injections and SEM (in brackets) are presented. Concentration ratio between the ethanol and water extract is also presented.

\begin{tabular}{|c|c|c|c|c|}
\hline Peak & Compound & $\begin{array}{l}\text { Ethanol extract } \quad(\mathrm{SEM}) \\
(\mathrm{mg} / \mathrm{g})\end{array}$ & $\begin{array}{l}\text { Water } \\
(\mathrm{mg} / \mathrm{g})\end{array} \quad$ extract $\quad(\mathrm{SEM})$ & $\begin{array}{l}\text { [Ratio] } \\
\left(\text { EtOH: } \mathrm{H}_{2} \mathrm{O}\right)\end{array}$ \\
\hline 1 & $(+)$-catechin ${ }^{a}$ & $0.497(0.033)$ & $1.145(0.011)$ & 0.43 \\
\hline 2 & Morroniside $^{a}$ & $106.169(0.887)$ & $127.824(0.232)$ & 0.83 \\
\hline 3 & (-)-epicatechin ${ }^{\mathrm{a}}$ & $6.226(0.053)$ & $3.786(0.025)$ & 1.64 \\
\hline 4 & Taxifolin-3-O-glucoside ${ }^{a}$ & $90.659(0.433)$ & $39.094(0.138)$ & 2.32 \\
\hline 5 & Betulinic acid ${ }^{\mathrm{a}}$ & $4.074(0.036)$ & $0.038(0.001)$ & 107.21 \\
\hline 6 & Ursolic acid $^{\mathrm{a}}$ & $1.769(0.046)$ & $0.019(0.001)$ & 93.11 \\
\hline 7 & Quercetin-3-O-galactoside & $34.833(0.734)$ & $20.784(0.261)$ & 1.67 \\
\hline 8 & Rutin & Trace $^{b}$ & Trace & -- \\
\hline 9 & Quercetin-3-O-glucoside ${ }^{c}$ & $1.398(0.041)$ & $1.118(0.030)$ & 1.25 \\
\hline 10 & Luteolin-7-O-glucoside & n.d. ${ }^{d}$ & n.d. & -- \\
\hline 11 & Myricetin & n.d. & n.d. & -- \\
\hline 12 & Kaempferol-3-O-rutinoside & Trace $^{b}$ & Trace & -- \\
\hline \multicolumn{5}{|c|}{$\begin{array}{l}\text { a } \text { significant difference between water and ethanol extracts }(\mathrm{p}<0.001) \\
{ }^{b} \text { detected in trace amounts } \\
{ }^{c} \text { significant difference between water and ethanol extracts }(\mathrm{p}<0.01) \\
\text { d } \text {.d. Not detected }\end{array}$} \\
\hline
\end{tabular}




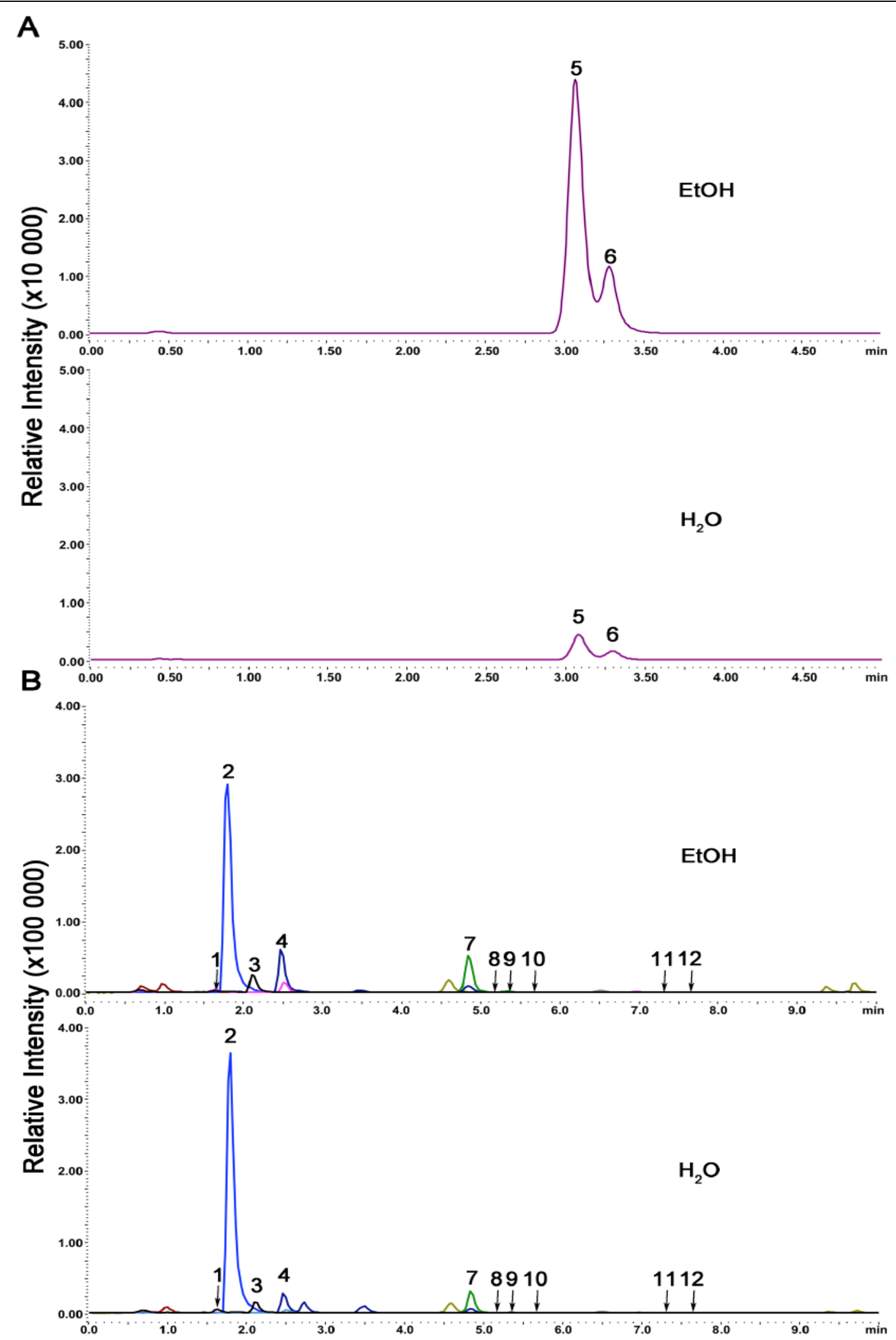

Figure 2. UPLC-ESI-MS chromatograms showing the relative intensity for compounds in the ethanol (EtOH) and water $\left(\mathrm{H}_{2} \mathrm{O}\right)$ extracts analyzed via method A for triterpenes $(\mathrm{A})$ and method B for the non-terpene compounds $(\mathrm{B}) .1 .(+)$-catechin, 2. morroniside, 3. (-)-epicatechin, 4. taxifolin-3-O-glucoside, 5. betulinic acid, 6. ursolic acid and 7. quercetin-3-Ogalactoside, 8. rutin, 9. quercetin-3-O-glucoside, 10. luteolin-7-O-glucoside, 11. myricetin, 12. kaempferol-3-O-rutinoside. 
seen by their early retention time and $\log \mathrm{P}$ values, and hence more readily extracted in the more polar solvent (13).

Quercetin-3-O-galactoside and morroniside, active substances of $S$. purpurea $(11,18,19)$, were present in similar amounts between the two extracts. Betulinic acid and ursolic acid were present in much larger quantities in the ethanol extract but to date have not been identified as actives. This, however, may be due to their high $\log$ P values. According to Lipinski's Rule of Five describing drug like substances, substances with $\log \mathrm{P}$ values higher than five are less likely to be absorbed (20). Quercetin-3-O-galactoside, as well as the other phenolics, are more drug like as their $\log \mathrm{P}$ values are lower than five, while those for betulinic acid or ursolic acid are greater than seven. However, discrimination of bioactive substances based on their $\log \mathrm{P}$ values alone is not ideal, as it does not apply to substances that are actively transported (21) or take into account a matrix effect, which in this instance would be the plant extract. Preliminary in vitro and in vivo work has shown that ursolic acid and betulinic acid exhibit some antidiabetic activity (22-27). Thus, it would be interesting to further explore the potential antidiabetic mechanism of betulinic acid and ursolic acid in more detail and determine why they are not the active principles in our assays.

An ethanol extract is generally preferred in biological assays as water can extract other cellular components that may mask or interfere with potential active substances $(7,8)$. This could translate to a decreased, altered, or no activity in an in vitro assay. An exception to this preference would be in immunological studies, where proinflammatory polysaccharides may be necessary
(28). This has been particularly important in the case of Echinacea (29) or ginseng (30), where the water extract has been shown to be quite proinflammatory in comparison to the ethanol one. This highlights the complexities of examining botanical samples where the activity may be related to the antagonistic or synergistic effect of many substances.

Although previously identified as minor components of $S$. purpurea (31), luteolin-7-Oglucoside and myricetin were not present in these extracts at the detection limit. Previous phytochemical analysis of the leaves of this species showed that these two substances were present in trace quantities. Seasonal and geographic variability in phytochemical content may account for these substances not being present at this level in the plant material used in this study.

$S$. purpurea extracts and isolated major constituent substances showed activity in a wide variety of antidiabetic assays (Table 4). In conclusion, most of the phenolic substances with antidiabetic properties in $S$. purpurea and other Cree botanical plants (10) showed a somewhat similar profile in both water and alcohol extracts, although amounts tend to be higher in alcohol. Thus, these extracts are expected to have generally comparable pharmacology with some predictable differences. In other situations, where lipophilic substances such as betulinic acid or ursolic acid are the active principles, the bioactivity is likely to be dramatically different between alcohol and water extracts. These findings demonstrate that both aqueous and ethanolic extracts may need to be evaluated when examining traditionally prepared medicines which are based on some form of water extraction.

Table 3. Lipophilicity ( $\log \mathrm{P})$ values for the 12 targeted compounds. Lipohilicity was determined using ChemBioDraw Ultra 13.0 software.

\begin{tabular}{lll}
\hline Peak & Compound & LogP \\
\hline 1 & (+)-catechin & 1.5 \\
2 & Morroniside & -1.77 \\
3 & (-)-epicatechin & 1.5 \\
4 & Taxifolin-3-O-glucoside & -1.16 \\
5 & Betulinic acid & 7.38 \\
6 & Ursolic acid & -1.33 \\
7 & Quercetin-3-O-galactoside & -2.28 \\
8 & Rutin & -1.39 \\
9 & Quercetin-3-O-glucoside & -0.33 \\
10 & Luteolin-7-O-glucoside & -0.04 \\
11 & Myricetin & -1.89 \\
\hline
\end{tabular}


Table 4. Summation of known antidiabetic activity of Sarracenia purpurea extracts and major constituent substances.

\begin{tabular}{|c|c|c|c|}
\hline Extract/Compound & Concentration & Effect & Reference \\
\hline Catechin & $8.35 \mu \mathrm{g} / \mathrm{mL}(\mathrm{IC} 50)$ & Antiglycation activity & 32 \\
\hline Catechin & $3.15 \mu \mathrm{g} / \mathrm{mL}(\mathrm{IC} 50)$ & Antiglycation activity & 19 \\
\hline Morroniside & $2.5 \mu \mathrm{g} / \mathrm{mL}$ & $\begin{array}{l}\text { Neuroprotection in } \mathrm{PC} 12 \text { cells in state of high } \\
\text { glucose }\end{array}$ & 19 \\
\hline Myricetin & $0.86 \mu \mathrm{g} / \mathrm{mL}(\mathrm{IC} 50)$ & Antiglycation activity & 19 \\
\hline Quercetin-3-O-galactoside & $60.5 \mu \mathrm{M}(\mathrm{EC} 50)$ & Increased glucose uptake in muscle cells & 11 \\
\hline Quercetin-3-O-glucoside & $0.5 \mu \mathrm{M}$ & $\begin{array}{l}\text { Neuroprotection in } \mathrm{PC} 12 \text { cells in state of high } \\
\text { glucose }\end{array}$ & 18 \\
\hline Quercetin-3-O-galactoside & $2.86 \mu \mathrm{g} / \mathrm{mL}(\mathrm{IC} 50)$ & Antiglycation activity & 32 \\
\hline Quercetin-3-glucoside & 50 and $100 \mu \mathrm{M}$ & Stimulated AMPK signaling pathway & 33 \\
\hline Quercetin-3-O-galactoside & 50 and $100 \mu \mathrm{M}$ & Stimulated AMPK signaling pathway & 33 \\
\hline Quercetin-3-O-galactoside & $0.5 \mu \mathrm{g} / \mathrm{mL}$ & $\begin{array}{l}\text { Neuroprotection in } \mathrm{PC} 12 \text { cells in state of high } \\
\text { glucose }\end{array}$ & 19 \\
\hline Rutin & $2.5 \mu \mathrm{M}$ & $\begin{array}{l}\text { Neuroprotection in PC12 cells in state of high } \\
\text { glucose }\end{array}$ & 18 \\
\hline Rutin & $4.14 \mu \mathrm{g} / \mathrm{mL}(\mathrm{IC} 50)$ & Antiglycation activity & 19 \\
\hline S. purpurea, ethanol & $38.6 \mu \mathrm{g} / \mathrm{mL}(\mathrm{IC} 50)$ & Antiglycation activity & 19 \\
\hline S. purpurea, ethanol & $5 \mu \mathrm{g} / \mathrm{mL}$ & $\begin{array}{l}\text { Neuroprotection in PC12 cells in state of high } \\
\text { glucose }\end{array}$ & 19 \\
\hline S. purpurea, ethanol & $100 \mu \mathrm{g} / \mathrm{mL}$ & $\begin{array}{l}\text { Increased glucose uptake in muscle cells and } \\
\text { adipocytes }\end{array}$ & 34,35 \\
\hline S. purpurea, ethanol & $100 \mu \mathrm{g} / \mathrm{mL}$ & $\begin{array}{l}\text { Neuroprotection in PC12 cells in states of high and } \\
\text { low glucose }\end{array}$ & 34 \\
\hline S. purpurea, ethanol & $100 \mu \mathrm{g} / \mathrm{mL}$ & Stimulated AMPK signaling pathway & 35 \\
\hline S. purpurea, ethanol & $25 \mu \mathrm{g} / \mathrm{mL}$ & Stimulate AMPK signaling pathway & 36 \\
\hline $\begin{array}{l}\text { S. purpurea, ethanol and } \\
\text { water extracts }\end{array}$ & $100 \mu \mathrm{g} / \mathrm{mL}$ & $\begin{array}{l}\text { Increased glucose uptake in muscle cells by } \\
\text { activating AMPK or insulin signaling pathways }\end{array}$ & 37 \\
\hline $\begin{array}{l}\text { S. purpurea, ethanol and } \\
\text { water extracts }\end{array}$ & $25 \mu \mathrm{g} / \mathrm{mL}$ & $\begin{array}{l}\text { Increased glucose uptake in liver cells by activating } \\
\text { AMPK and insulin signaling pathways }\end{array}$ & 37 \\
\hline
\end{tabular}

\section{ACKNOWLEDGMENTS}

Very special thanks are due to Elizabeth Coon Come, Harriet Matoush, Sandy Matoush, Charlotte Petawabano, Laurie Petawabano, Pat Petawabano, Sam Petawabano, Simeon Petawabano, and Smally Petawabano from the Cree Nation of Mistissini, and Agnes Kawapit, Eliza Kawapit, Abraham Mamianskum, and Juliet Mamianskum from Whapmagoostui First Nation as well as to Cree Elders of both nations of the Eeyou Istchee who kindly agreed to be interviewed. They made this article possible by allowing us to use, for the purposes of this research, their knowledge relating to medicinal plants, transmitted to them by their elders. Their trust has also enabled a useful exchange between Indigenous knowledge and Western science. This project was funded by a Canadian Institutes of Health Research (CIHR) Team Grant in Aboriginal Antidiabetic Medicines CTP-79855 to AC, PH, JTA, and BCF and CIHR
MOP 62826 to JA. CC is a recipient of the NSERC Canada Graduate Scholarship and a CIHR Training Program in Neurodegenerative Lipidomics Graduate Student Scholarship. BWR is a recipient of the NEAHR-ACADRE PhD Fellowship by CIET Canada.

\section{CONFLICT OF INTEREST}

The authors have declared that there is no conflict of interest.

\section{REFERENCES}

1. Leduc C, Coonishish J, Haddad P, Cuerrier A. Plants used by the Cree Nation of Eeyou Istchee (Quebec, Canada) for the treatment of diabetes: A novel approach in quantitative ethnobotany. $\mathbf{J}$ Ethnopharmacol. 2006;105(1-2):55-63.

2. Fraser MH, Cuerrier A, Haddad PS, Arnason JT, Owen PL, Johns T. Medicinal plants of Cree communities (Quebec, Canada): antioxidant activity 
of plants used to treat type 2 diabetes symptoms. Can J Physiol Pharmacol. 2007;85(11):1200-14.

3. Kuzmina E, Lejeune P, Dannenbaum D, Torrie JE. Cree Diabetes Information System 2009 Annual Report. Chisasibi: Cree Board of Health and Social Services of James Bay, 2010.

4. Soares MO, Alves RC, Pires PC, Oliveira MB, Vinha AF. Angolan Cymbopogon citratus used for therapeutic benefits: Nutritional composition and influence of solvents in phytochemicals content and antioxidant activity of leaf extracts. Food Chem Toxicol. 2013.

5. Zarnowski R, Suzuki Y. Expedient Soxhlet extraction of resorcinolic lipids from wheat grains. Journal of Food Composition and Analysis. 2004;17(5):649-63.

6. Wang LJ, Weller CL. Recent advances in extraction of nutraceuticals from plants. Trends Food Sci Technol. 2006;17(6):300-12.

7. Spigno G, Trarnelli L, De Faveri DM. Effects of extraction time, temperature and solvent on concentration and antioxidant activity of grape marc phenolics. J Food Eng. 2007;81(1):200-8.

8. Sharma M, Arnason JT, Burt A, Hudson JB. Echinacea extracts modulate the pattern of chemokine and cytokine secretion in rhinovirusinfected and uninfected epithelial cells. Phytother Res. 2006;20(2):147-52.

9. Ellison AM, Butler ED, Hicks EJ, Naczi RF, Calie PJ, Bell CD, et al. Phylogeny and biogeography of the carnivorous plant family Sarraceniaceae. PLoS One. 2012;7(6):e39291.

10. Muhammad A, Haddad PS, Durst T, Arnason JT. Phytochemical constituents of Sarracenia purpurea L. (pitcher plant). Phytochemistry. 2013;94:238-42.

11. Muhammad A, Guerrero-Analco JA, Martineau LC, Musallam L, Madiraju P, Nachar A, et al. Antidiabetic compounds from Sarracenia purpurea used traditionally by the Eeyou Istchee Cree First Nation. J Nat Prod. 2012;75(7):1284-8.

12. Saleem A, Harris CS, Asim M, Cuerrier A, Martineau L, Haddad PS, et al. A RP-HPLC-DADAPCI/MSD method for the characterisation of medicinal Ericaceae used by the Eeyou Istchee Cree First Nations. Phytochem anal: PCA. 2010;21(4):328-39.

13. Lapornik B, Prosek M, Wondra AG. Comparison of extracts prepared from plant by-products using different solvents and extraction time. J Food Eng. 2005;71(2):214-22.

14. Adedapo A, Jimoh F, Afolayan A. Comparison of the nutritive value and biological activities of the acetone, methanol and water extracts of the leaves of Bidens pilosa and Chenopodium album. Acta Pol Pharm. 2011;68(1):83-92.

15. Sultana B, Anwar F, Ashraf M. Effect of extraction solvent/technique on the antioxidant activity of selected medicinal plant extracts. Molecules. 2009;14(6):2167-80.

16. Bergeron C, Livesey JF, Awang DVC, Arnason JT, Rana J, Baum BR, et al. A quantitative HPLC method for the quality assurance of Echinacea products on the North American market. Phytochem Anal. 2000;11(4):207-15.

17. Harris CS, Burt AJ, Saleem A, Le PM, Martineau LC, Haddad PS, et al. A single HPLC-PADAPCI/MS method for the quantitative comparison of phenolic compounds found in leaf, stem, root and fruit extracts of Vaccinium angustifolium. Phytochem Anal. 2007;18(2):161-9.

18. Harris CS, Asim M, Saleem A, Haddad PS, Arnason JT, Bennett SA. Characterizing the cytoprotective activity of Sarracenia purpurea L., a medicinal plant that inhibits glucotoxicity in $\mathrm{PC} 12$ cells. BMC Complement Altern Med. 2012;12:245.

19. Harris CS, Beaulieu LP, Fraser MH, McIntyre KL, Owen PL, Martineau LC, et al. Inhibition of advanced glycation end product formation by medicinal plant extracts correlates with phenolic metabolites and antioxidant activity. Planta Med. 2011;77(2):196-204.

20. Lipinski CA, Lombardo F, Dominy BW, Feeney PJ. Experimental and computational approaches to estimate solubility and permeability in drug discovery and development settings. Adv Drug Deliv Rev. 2001;46(1-3):3-26

21. Leeson P. Drug discovery: Chemical beauty contest. Nature. 2012;481(7382):455-6.

22. de Melo CL, Queiroz MG, Arruda Filho AC, Rodrigues AM, de Sousa DF, Almeida JG, et al. Betulinic acid, a natural pentacyclic triterpenoid, prevents abdominal fat accumulation in mice fed a high-fat diet. J Agric Food Chem. 2009;57(19):8776-81.

23. Jang SM, Kim MJ, Choi MS, Kwon EY, Lee MK. Inhibitory effects of ursolic acid on hepatic polyol pathway and glucose production in streptozotocininduced diabetic mice. Metabolism. 2010;59(4):5129.

24. Jang SM, Yee ST, Choi J, Choi MS, Do GM, Jeon $\mathrm{SM}$, et al. Ursolic acid enhances the cellular immune system and pancreatic beta-cell function in streptozotocin-induced diabetic mice fed a high-fat diet. Int Immunopharmacol. 2009;9(1):113-9.

25. Jayaprakasam B, Olson LK, Schutzki RE, Tai MH, Nair MG. Amelioration of obesity and glucose intolerance in high-fat-fed $\mathrm{C} 57 \mathrm{BL} / 6$ mice by anthocyanins and ursolic acid in Cornelian cherry (Cornus mas). J Agric Food Chem. 2006;54(1):2438.

26. Oh CJ, Kil IS, Park CI, Yang CH, Park JW. Ursolic acid regulates high glucose-induced apoptosis. Free Radic Res. 2007;41(6):638-44. 
27. Zhang W, Hong D, Zhou Y, Zhang Y, Shen Q, Li JY, et al. Ursolic acid and its derivative inhibit protein tyrosine phosphatase $1 \mathrm{~B}$, enhancing insulin receptor phosphorylation and stimulating glucose uptake. Biochim Biophys Acta. 2006;1760(10):1505-12.

28. Walshe-Roussel B. An ethnobiological investigation of the Q'eqchi' Maya and Cree of Eeyou Istchee immunomodulatory therapies. $\mathrm{PhD}$ Thesis. University of Ottawa. 2013.

29. Singh N. A comparison of both water and ethanol extracts prepared from Echinacea purpurea and Echinacea angustifolia on the response to Influenza $\mathrm{A} / \mathrm{PR} / 8 / 34$ infection in mice. MSc. Thesis. Iowa State University. 2010.

30. Assinewe VA, Amason JT, Aubry A, Mullin J, Lemaire I. Extractable polysaccharides of Panax quinquefolius L. (North American ginseng) root stimulate TNFalpha production by alveolar macrophages. Phytomedicine. 2002;9(5):398-404.

31. Rapinski M. Variation of certain secondary metabolites along a latitudinal gradient from medicinal plants used by the Cree of Eeyou Istchee. MSc. Thesis. Université de Montréal. 2013.

32. Beaulieu LP, Harris CS, Saleem A, Cuerrier A, Haddad PS, Martineau LC, Bennett SA, Arnason JT. Inhibitory effect of the Cree traditional medicine wiishichimanaanh (Vaccinium vitis-idaea) on advanced glycation endproduct formation: identification of active principles. Phytother Res. 2010;24(5):741-747.

33. Eid HM, Martineau LC, Saleem A, Muhammad A, Vallerand D, Benhaddou-Andaloussi A, Nistor L, Afshar A, Arnason JT, Haddad PS. Stimulation of AMP-activated protein kinase and enhancement of basal glucose uptake in muscle cells by quercetin and quercetin glycosides, active principles of the antidiabetic medicinal plant Vaccinium vitis-idaea. Mol Nutr Food Res. 2010:54(7):991-1003.
34. Spoor DC, Martineau LC, Leduc C, BenhaddouAndaloussi A, Meddah B, Harris C, Burt A, Fraser $\mathrm{MH}$, Coonishish J, Joly E, Cuerrier A, Bennett SA, Johns T, Prentki M, Arnason JT, Haddad PS. Selected plant species from the Cree pharmacopoeia of northern Quebec possess anti-diabetic potential. Can J Physiol Pharmacol. 2006:84(8-9):847-858.

35. Martineau LC, Adeyiwola-Spoor DC, Vallerand D, Afshar A, Arnason JT, Haddad PS. Enhancement of muscle cell glucose uptake by medicinal plant species of Canada's native populations is mediated by a common, metformin-like mechanism. J Ethnopharmacol. 2010;127(2):396-406.

36. Nachar A, Vallerand D, Musallam L, Lavoie L, Badawi A, Arnason J, Haddad PS. The action of antidiabetic plants of the canadian james bay cree traditional pharmacopeia on key enzymes of hepatic glucose homeostasis. Evid Based Complement Alternat Med. 2013;2013:189819. doi: $10.1155 / 2013 / 189819$.

37. Shang N, Saleem A, Musallam L, Walshe-Roussel B, Badawi A, Cuerrier A, Arnason JT, Haddad PS. Novel Approach to Identify Potential Bioactive Plant Metabolites: Pharmacological and Metabolomics Analyses of Ethanol and Hot Water Extracts of Several Canadian Medicinal Plants of the Cree of Eeyou Istchee. PLoS One. 2015;10(8):e0135721. doi: 10.1371/journal.pone.0135721. 